\title{
Comparative Growth Performance of Genetically Male, Sex- Reversed, and Mixed-Sex Nile Tilapia (Oreochromis niloticus) Reared in Earthen Ponds in Sagana, Kenya
}

\author{
Mary A. Opiyo ${ }^{1, *}$ (D), Kevin O. Obiero², Jacob Abwao ${ }^{1}$, Fonda Jane Awuor ${ }^{1}$, Domitila \\ Kyule $^{1}$, Jonathan Munguti ${ }^{1}$
}

\author{
${ }^{1}$ Kenya Marine and Fisheries Research Institute, National Aquaculture Research Development and Training Center, \\ P.O. Box 451-10230, Sagana, Kenya \\ ${ }^{2}$ Kenya Marine and Fisheries Research Institute, Sangoro Aquaculture Station, Pap-Onditi 136-40111, Kenya.
}

\section{Article History}

Received 26 June 2020

Accepted 13 November 2020

First Online 19 November 2020

\section{Corresponding Author}

Tel.: +254721782665

E-mail: marybede@gmail.com

\section{Keywords}

Monosex tilapia

All male tilapia

$17 \alpha$-methyltestosterone

\begin{abstract}
Nile tilapia (Oreochromis niloticus) culture has been faced by challenges of prolific breeding and early maturity of mixed-sex tilapia that can be solved by the culture of all-male tilapia. A study was conducted to compare the growth performance, survival and condition factor of genetically male tilapia (GMT), sex-reversed tilapia (SRT) and mixed-sex tilapia (MST) cultured in earthen ponds. Fingerlings of initial weights ranging from 0.41 to $0.91 \mathrm{~g}$ for GMT, SRT and MST were stocked in $150 \mathrm{~m}^{2}$ earthen ponds in triplicates at 3 fish $\mathrm{m}^{-2}$ and fed on a 35\% crude protein diet. After 180 days culture period, the final body weights of SRT $(202.82 \pm 7.30 \mathrm{~g})$ was significantly higher than GMT $(174.34 \pm 3.71 \mathrm{~g})$ and MST $(148.06 \pm 4.60 \mathrm{~g})(\mathrm{P}<0.05)$. The survival of MST $(74.11 \pm 4.73 \%)$ was higher than GMT $(67.22 \pm 9.72 \%)$ and SRT $(65.22 \pm 2.94 \%)$ but no significant differences were observed $(P>0.05)$. The condition factor of all the fish was above 1 and was significantly different between the groups $(P<0.05)$. This study demonstrates that SRT has superior growth performance than GMT and MST hence sex reversal should be used for improved Nile tilapia production.
\end{abstract}

\section{Introduction}

Aquaculture contributes approximately $50 \%$ of fish production globally and is considered one of the fastestgrowing agri-food production sectors worldwide (FAO, 2018). In the developing countries, aquaculture has a great potential in enhancing food and nutrition security and bridging the food fish demand-supply gap (Allison, 2011; Béné et al., 2016). Capture fisheries has stagnated over the recent past hence the need to refocus on aquaculture production (Ansah et al., 2014). The aquaculture sector has grown rapidly in Kenya over the last decade and plays an increasingly important role in national food fish supply. Freshwater fish account for approximately $98 \%$ of Kenya's reported aquaculture production (KMFRI, 2017). The high freshwater fish production is attributed to the government intervention between the year 2009 to 2012 through the inter- sectoral economic stimulus program (Musa et al., 2012). The fisheries component; Fish Farming Enterprise Productivity Program (FFEPP) enhanced aquaculture production from 4,218 metric tons (MT) in 2006 to a peak of 24,096 MT in 2014 (Opiyo et al., 2018). However, aquaculture production registered depressed performance in the last three years, with total production dropping from 24,096 MT in 2014 to 18,542 MT in 2019 (KNBS, 2020). The outcome arising from the government interventions has remained marginal, due to high tax on inputs, little efforts in improving the enabling environment for aquaculture investment and infrastructure to enhance inputs accessibility, extension services, marketing and most importantly promotion of best management practices that involve genetic improvement in the existing hatcheries (Chu et al., 2018). Inadequate monitoring and evaluation of hatcheries in Kenya to ensure quality and adherence to 
set guidelines has resulted to poor quality seeds supplied to fish farmers (Nyonje et al., 2018).

Tilapias are among the most important warmwater fishes cultured globally (Charo-Karisa et al., 2006). Among the wide variety of tilapias, Nile tilapia (Oreochromis niloticus) is the most cultured fish species in Kenya contributing $80 \%$ of aquaculture production (Mbugua, 2008; Opiyo et al., 2018). O. niloticus has favourable aquaculture characteristics which include high tolerance to poor water quality, market acceptance, breeding in captivity, efficient utilization of plant-based diets and resistance to disease (Fitzsimmons, 2000; Liti et al., 2005; El-Greisy \& ElGamal, 2012). Other indigenous tilapia species, though not popular include Singida tilapia (Oreochromis esculentus, Graham 1928); Victoria tilapia (Oreochromis variabilis, Boulenger 1906); and, Redbelly tilapia (Coptodon zillii, Gervais 1848). Africa's and Kenya's contribution to tilapia production worldwide is still minimal despite the existing potential and resources that can promote aquaculture production including; favourable climate, good soil and sufficient water (FAO, 2018; Opiyo et al., 2018). In Kenya, the culture of Nile tilapia has been faced by significant setbacks from inbreeding, uncontrolled reproduction resulting in stunted growth and low market value (Ngugi et al., 2007). These challenges can be addressed through production of all male tilapia and genetic improvement initiatives.

Monosex tilapia production through sex reversal has been the most commonly used method embraced by farmers globally (Mair \& Little, 1991; Celik et al., 2011). Monosex male tilapia culture enhances the production of faster-growing males and control challenges emanating from unwanted reproduction, overcrowding and harvest of undersized fish due to feeding competition (Kamaruzzaman et al., 2009; Singh et al., 2017). In this technology, the metabolic energy in males is directed towards growth and masculinization (El-Greisy \& El-Gamal, 2012; Amoussou et al., 2019). In females, however, the metabolic energy is usually channeled towards reproduction leading to slow growth (El-Greisy \& El-Gamal, 2012). The most preferred production method of all-male tilapia involves oral administration of diet impregnated with the male hormone, $17 \alpha$-methyltestosterone (17- $\alpha-\mathrm{MT})$ to tilapia fry at day one after yolk absorption when they are still sexually undifferentiated for 28-30 days (Phelps \& Popma, 2000).

As a result of unpredictable seed quality and environmental concerns over the use of hormones for sex reversal, genetic research led to the production of genetically male tilapia (GMT), where YY "super males" are crossed with genetically female tilapia (XX females) to produce all-male (XY males) progeny and have been undertaken for years for commercial applications (Mair et al., 1997; Chen et al., 2018). The GMTs are all-male and are supposed to have higher growth, delayed maturity and higher yield than other male tilapias.
Production of male tilapia through $Y Y$ technology is considered environmentally friendly and reliable. However, limited information exists in Kenya on the growth performance and yield of genetically male tilapia produced from the super YY males. Although improved tilapia strains have significantly increased the productivity, farm output and profit levels associated with tilapia farming is still very low in Kenya and other Sub-Saharan countries compared to China and other Asian countries (Chen et al., 2018), leading to low production (Kumar \& Engle, 2016). In commercial aquaculture facilities, the growth performance of fish is the most important influencing factor concerning economic benefit (Lugert, et al., 2016). Therefore, determination of optimal environmental conditions for fish growth and achievement of the desirable market size is essential for optimizing aquaculture production (Azaza et al., 2008). This study was designed to compare the growth performance of genetically male tilapia (GMT), hormonally sex-reversed male tilapia (SRT) and mixed-sex tilapia (MST) reared in earthen pond culture system in Kenya.

\section{Materials and Methods}

\section{Study Area and Experimental Fish}

The study was conducted at the Kenya Marine and Fisheries Research Institute (KMFRI) - Sagana Centre (located at $0^{\circ} 39^{\prime} \mathrm{S}, 37^{\circ} 20^{\prime} \mathrm{E}$ and $1230 \mathrm{~m}$ above the sea level). The culture units were nine earthen ponds of 150 $\mathrm{m}^{2}$ each stocked with 450 Nile tilapia fingerlings at the rate of 3 fish $\mathrm{m}^{-2}$. The genetically male tilapia from $Y Y$ "super males" and genetically females (GMT) were purchased from Athi Fish Farm and Hatchery located in Athi River town, Kenya. Both the YY males and genetically female tilapias were initially sourced from Til Aqua International, the Netherlands by Jambo Fish Western Ltd. The YY male and genetically female broodstock were expected to produce genetically allmale tilapia (GMT) with a male ratio $>99 \%$ without use of hormones. Sex reversed tilapia fingerlings (SRT) were produced at KMFRI Sagana hatchery through hormonal sex reversal using $17 \alpha$-methyltestosterone treated diet (60 $\mathrm{mg} \mathrm{kg}^{-1}$ feed) prepared by the alcohol evaporation technique (Shelton et al., 1978). Fry were fed on hormone-laced feed for 28 days and reared in a nursery for 2 weeks before the experiment. Mixed-sex Nile tilapia (MST) fingerlings were sourced from KMFRI Sagana hatchery.

\section{Experimental Design}

The experiment was conducted for 180 days (August 2018 to January 2019). During these months, August was the coldest month, with average water temperatures of $22^{\circ} \mathrm{C}$ while November was the hottest month with an average water temperature of $26^{\circ} \mathrm{C}$. Before the start of the experiment, fish were transferred 
into different hapa nets installed in an earthen pond where they were fed three times a day with a standard $35 \%$ crude protein (CP) commercial diet (Aller Aqua feeds) for 2 weeks as an acclimatization period before introduction into the grow-out earthen ponds. The ponds were limed and treated to remove any unwanted fish. The GMT, SRT and MST fingerlings of average body weight of $0.91 \pm 0.06 \mathrm{~g} ; 0.41 \pm 0.02 \mathrm{~g}$ and $1.42 \pm 0.08 \mathrm{~g}$ respectively, were stocked in $150 \mathrm{~m}^{2}$ grow-out earthen ponds at a stocking density of 3 fish $\mathrm{m}^{-2}$. Fish were fed twice daily on commercial tilapia diets (35\% CP Aller Aqua feeds) at $5 \%$ body weight and reduced to $3 \%$ body weight in the fourth month. The feed was administered to fish using pre-weighed feed containers depending on the biomass in the pond.

\section{Water Quality Monitoring}

Water quality parameters including Dissolved oxygen (DO) concentrations, temperature, and $\mathrm{pH}$ were measured in situ weekly using a multi-parameter water quality meter, model H19828 (Hanna Instruments Ltd., Chicago, and IL., USA). Total Ammonia Nitrogen (TAN), Total nitrogen (TN), Nitrates $\left(\mathrm{NO}_{2}\right)$, and Nitrites $\left(\mathrm{NO}_{3}\right)$, were measured weekly using standard laboratory water quality analysis methods by Boyd \& Tucker (1998).

\section{Fish Sampling}

Fish were sampled monthly using a seine net. A random sample of 30 fish was collected from each pond for individual weight and length measurements. The fish were weighed using an electronic balance (readability $0.01 \mathrm{~g}$ ) model KERN 572-33, Germany, and total length (cm) measured using a measuring board to the nearest $0.1 \mathrm{~cm}$ and returned to their respective ponds. At the end of the experimental period, fish were deprived of feed for 24 hours, all the experimental ponds were drained and all the fish were harvested, counted, and weighed individually. Fish growth performances were evaluated in terms of final total length $(\mathrm{cm})$, weight $(\mathrm{g})$, daily weight gain (DWG), specific growth rate (SGR), survival (\%), feed conversion ratio (FCR) and condition factor (K-Factor). The following formula were used for the calculations;

$$
\text { SGR (\%)=100 (InWt-InW0/t) }
$$

Where:-(In=natural logarithm, W0=initial weight $(\mathrm{g}), \mathrm{Wt}=$ final weight $(\mathrm{g})$ and $\mathrm{t}=$ time in days from stocking to harvesting.

$$
\begin{aligned}
& \text { Daily Weight gain }(\mathrm{g} / \text { day })=100(\mathrm{Wt}-\mathrm{W} 0) / \mathrm{t} \\
& \text { Condition factor }(\mathrm{K})=100 \mathrm{~W} / \mathrm{L}^{3}
\end{aligned}
$$

Where $\mathrm{K}$ is the condition factor, $\mathrm{L}$ is the total length of fish in $\mathrm{cm}$ while $\mathrm{W}$ is the weight of fish in grams.

$$
\begin{aligned}
& \text { FCR }=\text { feed given }(\mathrm{g}) / \text { /body weight gain }(\mathrm{g}) \\
& \text { Survival= }=\frac{\text { Number of fish harvested }}{\text { Number of fish stocked }} \times 100
\end{aligned}
$$

\section{Data Analysis}

Statistical data analysis was done for growth rate, SGR, FCR, and survival rates, using the Statistical Product and Service Solutions (SPSS Inc. version 20.0). Data were subjected to one-way analysis of variance (ANOVA) followed by Duncan multiple test for multiple comparisons. A statistical significance of $\mathrm{P}<0.05$ was considered for all analyses conducted.

\section{Results}

\section{Growth Performance}

The growth trends of the different groups of $O$. niloticus are presented in Figure 1 . Sex reversed tilapia

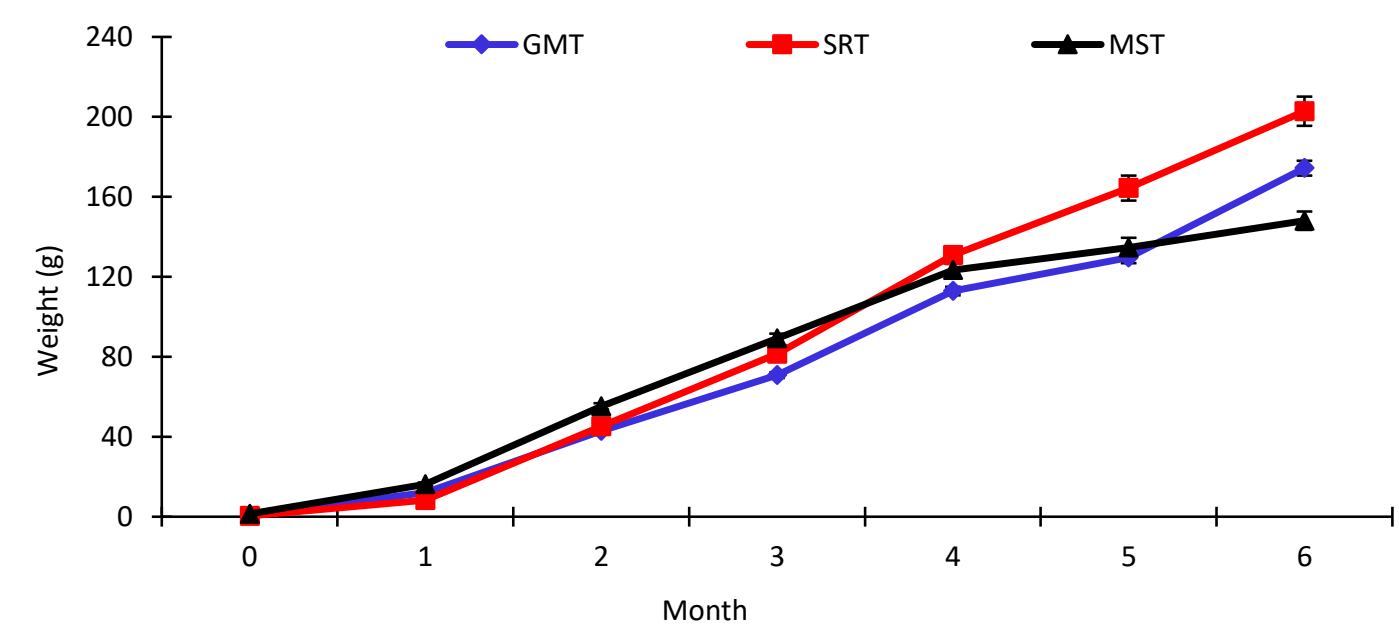

Figure 1. Growth curve of genetically male tilapia (GMT), sex reversed tilapia (SRT) and mixed sex tilapia (MST) reared in earthen ponds. 
(SRT) had significantly higher growth compared to the genetically male tilapia (GMT) and the mixed sex tilapia (MST). The sex-reversed tilapia achieved a final average weight of $202.82 \pm 7.30 \mathrm{~g}$. The lowest final mean body weight $(148.06 \pm 4.60 \mathrm{~g})$ was recorded in MST (Table 1). Generally, the low growth of the fish in all the treatments could be attributed to the low temperatures exhibited in August and September (temperature of an average of $22^{\circ} \mathrm{C}$ ). The growth performance of the different groups of $O$. niloticus under the study is shown in Table 1. Highest SGR and DWG were recorded in the SRT followed by the GMT. There was a significant difference in the final body weight, SGR, FCR, and DWG among the treatment $(P<0.001)$. The FCR was lower in SRT but was not significantly different from GMT while MST had significantly higher FCR $(P<0.001)$.

Fulton's condition factors were $1.74 \pm 0.01$, $1.81 \pm 0.02,1.78 \pm 0.01$ for GMT, SRT and MST respectively. This demonstrates that the condition factors of all the fish were above 1 and were significantly different between the treatments with SRT having the highest condition factor $(P<0.05)$. Length Weight Relationships (LWR) analysis indicated that the regression slope $b$ of the different fish were 3.11 for GMT, 3.11 for SRT and 3.06 for MST and were $\geq 3$ with an $R^{2}$ value of 1.00, 0.99 and 0.98 ; for GMT, SRT and MST respectively (Figure 2). Compared to the GMT and the MST, the proportion of males to females was significantly higher in SRT $(P<0.05)$. MST had the lowest male to female ratio value of $56.66 \%$. The percent survival of fish in all the groups was between 67.22 to $77.11 \%$. The highest survival was recorded in MST (74.11\%) followed by GMT (67.22\%) while the lowest survival was exhibited in the SRT group (65.22\%). However, there was no significant difference on survival between the different groups ( $P>0.05)$.

\section{Water Quality Parameters}

The water quality parameters during the experimental period are shown in Table 2. Dissolved oxygen (DO) ranged from 4.31-4.36 $\mathrm{mg} \mathrm{L}^{-1}$; temperature,
24.76-25.08 ${ }^{\circ} \mathrm{C} ; \mathrm{pH}, 7.70-7.74$; Total Ammonia nitrogen (TAN), 0.14-0.16 $\mathrm{mg} \mathrm{L}^{-1}$; Total nitrogen (TN), 1.58-1.62 $\mathrm{mg} \mathrm{L}^{-1}$; Nitrates $\left(\mathrm{NO}_{2}\right), 0.01-0.03 \mathrm{mg} \mathrm{L}^{-1}$ and Nitrites $\left(\mathrm{NO}_{3}\right), 0.01-0.02 \mathrm{mg} \mathrm{L}^{-1}$. The recorded water quality parameters did not show any significant differences among the treatments ( $P>0.05)$.

\section{Discussion}

The main objective of this study was to evaluate the growth performance of genetically male tilapia (GMT) to hormonally sex-reversed male tilapia (SRT) and mixed-sex tilapia (MST) reared in earthen ponds in Sagana, Kenya. At the end of 180 days of the experiment, all the tilapia groups had different final mean weight (FMW), specific growth rate (SGR), and daily weight gain (DWG). The SRT group exhibited higher final body weight, SGR, and DWG than the GMT and MST groups. These results contradict those of Islam et al. (2015) and Mair et al. (1995) in which the GMT had the highest mean average weight at the end of 105 days of the experiment. Mixed sex tilapia recorded a lower growth performance because of a higher proportion of females than the other monosex groups. This is attributed to the fact that female tilapia spend more energy in egg production and mouth-brooding hence exhibiting a lower growth rate compared to the males as posited by Chakraborty et al. (2011).

The results of the present study are similar to studies of Mbiru et al. (2016) who reported that sexreversed tilapia attained greater final weight compared to mixed-sex tilapia in Tanzania. Although many scientists have recorded the lack of a significant difference in growth between sex-reversed males and genetic male tilapia (Phelps \& Popma, 2000), the present study indicates that SRT had a significantly higher growth rate compared to MST confirming the findings of Mateen \& Ahmed (2007) and Chakraborty \& Banerjee (2012). The higher growth rate of SRT is a result of anabolic and androgenic impacts of $17 \alpha$ methyltestosterone hormone which advances male sexual traits in $O$. niloticus while simultaneously

Table 1. Growth parameters for genetically male tilapia (GMT), sex reversed tilapia (SRT) and mixed sex tilapia (MST) reared in earthen ponds

\begin{tabular}{|c|c|c|c|c|c|}
\hline \multirow{2}{*}{ Parameter } & \multicolumn{3}{|c|}{ Treatments } & \multirow{2}{*}{ F-value } & \multirow{2}{*}{$p$-value } \\
\hline & GMT & SRT & MST & & \\
\hline Initial length (cm fish-1) & $3.75 \pm 0.09^{a}$ & $3.08 \pm 0.04^{b}$ & $4.50 \pm 0.10^{c}$ & 72.78 & $<0.001$ \\
\hline Initial weight (g fish-1) & $0.91 \pm 0.06^{a}$ & $0.41 \pm 0.02^{b}$ & $1.42 \pm 0.08^{c}$ & 70.83 & $<0.001$ \\
\hline Final length (cm fish ${ }^{-1}$ ) & $21.44 \pm 0.16^{a}$ & $21.88 \pm 0.30^{\mathrm{a}}$ & $20.60 \pm 0.23^{b}$ & 7.41 & 0.01 \\
\hline Final weight ( $\mathrm{g} \mathrm{fish}^{-1}$ ) & $174.34 \pm 3.71^{\mathrm{a}}$ & $202.82 \pm 7.30^{\mathrm{b}}$ & $148.06 \pm 4.60^{c}$ & 25.51 & $<0.001$ \\
\hline SGR (\% day $\left.{ }^{-1}\right)$ & $2.62 \pm 0.03^{a}$ & $2.96 \pm 0.02^{b}$ & $2.27 \pm 0.02^{c}$ & 174.09 & $<0.001$ \\
\hline DWG & $0.83 \pm 0.02^{\mathrm{a}}$ & $0.96 \pm 0.03^{b}$ & $0.70 \pm 0.02^{c}$ & 26.76 & $<0.001$ \\
\hline FCR & $2.44 \pm 06^{a}$ & $2.33 \pm 0.10^{\mathrm{a}}$ & $3.26 \pm 0.10^{c}$ & 31.80 & $<0.001$ \\
\hline Condition Factor (K) & $1.74 \pm 0.01^{\mathrm{a}}$ & $1.81 \pm 0.02^{\mathrm{b}}$ & $1.78 \pm 0.01^{\mathrm{b}}$ & 6.09 & 0.002 \\
\hline \% Survival & $67.22 \pm 9.72^{\mathrm{a}}$ & $65.22 \pm 2.94^{\mathrm{a}}$ & $74.11 \pm 4.73^{a}$ & 5.05 & 0.627 \\
\hline$\%$ Males & $81.94 \pm 1.10^{a}$ & $94.45 \pm 1.36^{b}$ & $56.66 \pm 4.41^{c}$ & 62.99 & $<0.001$ \\
\hline
\end{tabular}

*Values are Mean \pm S.E of three replicates. Means having the same letter in the same row are not significantly different at $\mathrm{P}<0.05$ 
(a) GMT

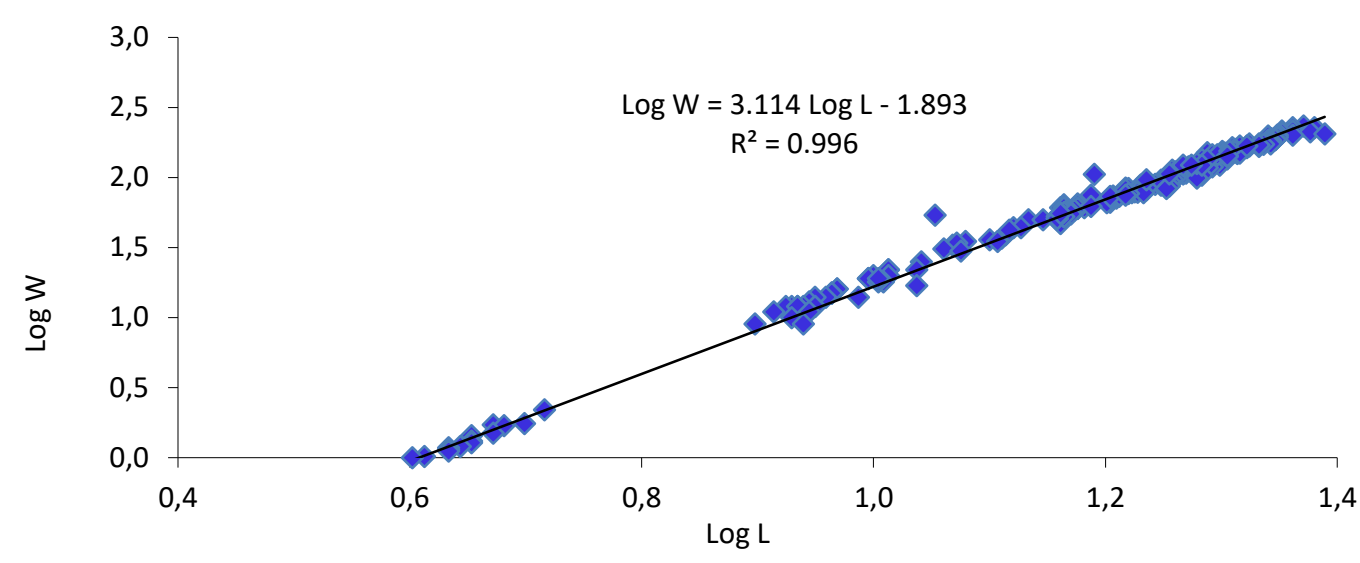

(b) SRT

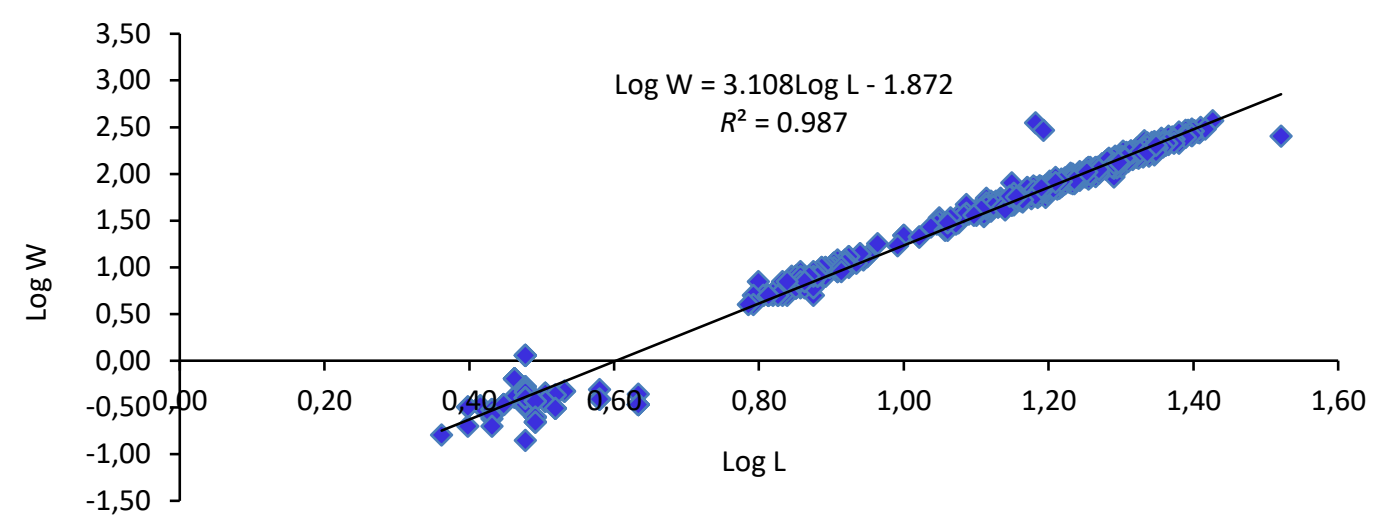

(c) MST

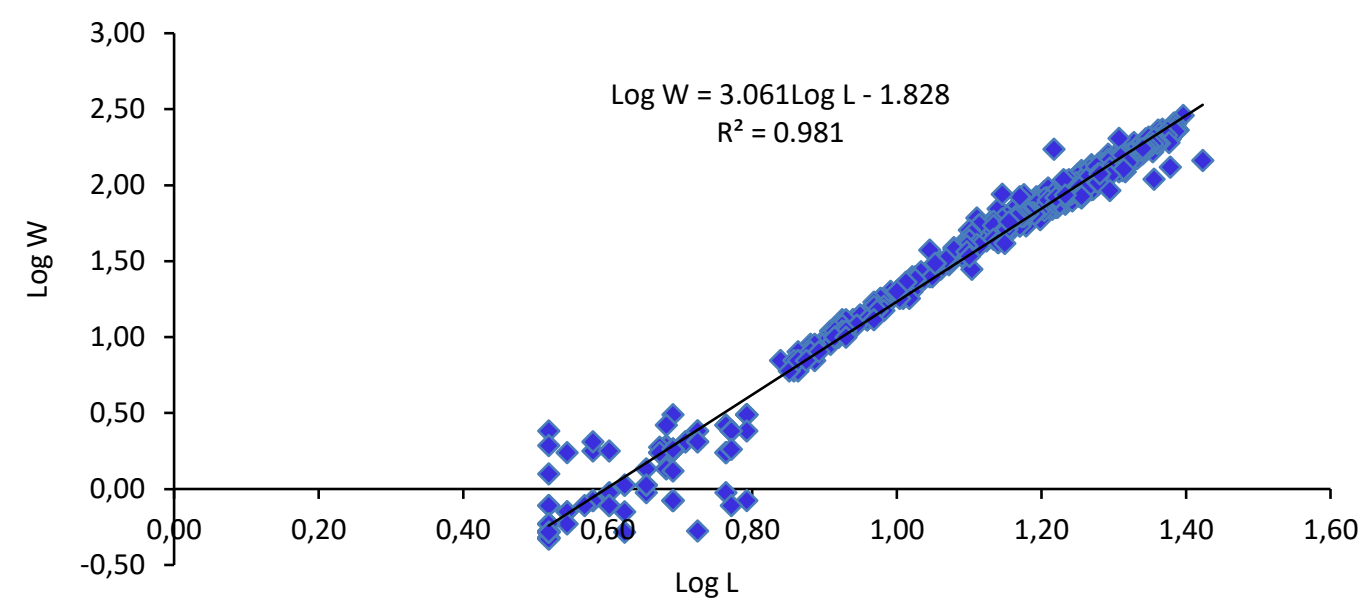

Figure 2. Length Weight relationship of (a) genetically male tilapia (GMT), (b) sex reversed tilapia (SRT), and (c) mixed sex tilapia (MST) reared in earthen ponds.

Table 2. Water quality parameters for genetically male tilapia (GMT), sex reversed tilapia (SRT) and mixed sex tilapia (MST) reared in earthen ponds

\begin{tabular}{lccc}
\hline Parameter & & Treatments & MST \\
\hline Dissolved oxygen $\left(\mathrm{mg} \mathrm{L}^{-1}\right)$ & GMT & SRT & $4.31 \pm 0.22^{\mathrm{a}}$ \\
Temperature $\left({ }^{\circ} \mathrm{C}\right)$ & $4.36 \pm 0.24^{\mathrm{a}}$ & $4.35 \pm 0.23^{\mathrm{a}}$ & $24.76 \pm 0.34^{\mathrm{a}}$ \\
pH & $25.08 \pm 0.38^{\mathrm{a}}$ & $24.80 \pm 0.25^{\mathrm{a}}$ & $7.70 \pm 0.60^{\mathrm{a}}$ \\
TAN (mg L-1) & $7.74 \pm 0.07^{\mathrm{a}}$ & $7.66 \pm 0.08^{\mathrm{a}}$ & $0.15 \pm 0.02^{\mathrm{a}}$ \\
TN $\left(\mathrm{mg} \mathrm{L}^{-1}\right)$ & $0.16 \pm 0.02^{\mathrm{a}}$ & $0.14 \pm 0.02^{\mathrm{a}}$ & $1.58 \pm 0.17^{\mathrm{a}}$ \\
TP $\left(\mathrm{mg} \mathrm{L}^{-1}\right)$ & $1.62 \pm 0.19^{\mathrm{a}}$ & $1.62 \pm 0.17^{\mathrm{a}}$ & $0.36 \pm 0.11^{\mathrm{a}}$ \\
Nitrates $\left(\mathrm{mg} \mathrm{L}^{-1}\right)$ & $0.39 \pm 0.01^{\mathrm{a}}$ & $0.37 \pm 0.11^{\mathrm{a}}$ & $0.01 \pm 0.00^{\mathrm{a}}$ \\
Nitrites $\left(\mathrm{mg} \mathrm{L}^{-1}\right)$ & $0.03 \pm 0.00^{\mathrm{a}}$ & $0.02 \pm 0.00^{\mathrm{a}}$ & $0.02 \pm 0.00^{\mathrm{a}}$ \\
\hline
\end{tabular}

*Values are Mean \pm S.E of three replicates. Means having the same letter in the same row are not significantly different at $\mathrm{P}<0.05$ 
promoting the growth of muscles (Khalil et al., 2011; ElGreisy \& El-Gamal, 2012). SRT achieved greater mean individual weight and length than the other groups and could be attributed to low energy expedited during courtship by males (Adamneh, 2013; Githukia et al., 2015). Moreover, several studies indicated that testosterone produces muscle hypertrophy by increasing muscle protein synthesis (Bhasin et al., 2001).

Feed conversion ratio (FCR) is an important economic indicator of how efficiently fish utilizes feed thereby reducing wastage. The lowest FCR $(2.33 \pm 0.1$ and 2.44 \pm 0.6 ) was observed in the MST and GMT respectively. The FCR observed in all-male groups was significantly lower than the MST group (3.26 \pm 0.10$)$. This is explained by the effect of sexual maturity where the female stops feeding during mouth brooding leaving uneaten feeds hence the suppressed growth in MST which has a higher proportion of females (Mair et al., 1995). Lower FCRs have been previously recorded in monosex tilapia by Islam et al. (2015) and Toguyeni et al. (1997) confirming the trend of monosex tilapia exhibiting better FCR than mixed-sex tilapia. The FCR in the current study was directly related to the proportion of males in the experimental groups. However, the low temperature recorded during the study could also have contributed to low feed intake hence the high FCR in the fish in all the experimental groups.

In the present study, the survival rate of $O$. niloticus was comparatively low (below 75\%) during the study period. There was no significant difference amongst the experimental groups. However, the MST treatment exhibited the highest survival and could be attributed to the sizes at stocking. The MST was stocked at a bigger size compared to the SRT and GMT thereby giving them the advantage of surviving during the early stages of grow-out (Sogard, 1997). In previous studies by Mamun et al. (2016) and Islam et al. (2015), the survival rates were above (90\%) which was higher compared to the present study perhaps due to limited control of the environmental conditions in the earthen ponds compared to indoor tanks. The fish were affected by the low temperatures recorded throughout the culture period affecting the survival. Survival rates higher than $85 \%$ were also recorded for SRT and GMT reared in tanks by Mbiru et al. (2016).

The Length Weight Relationship (LWR) during the culture period indicates that GMT and SRT had isometric growth, which is the ideal growth as recommended by Froese (2006). Condition factor is an indicator of the health condition and well-being of fish in their natural environment. According to Froese (2006), studying fish health condition using condition factor presumes that fish with higher condition factor values are in a better state. SRT had the highest condition factor $1.81 \pm 0.02$ followed by MST $1.78 \pm 0.01$ and finally GMT $1.74 \pm 0.01$. The condition factor in all groups was higher than the ones recorded in SRT (1.46) and GMT (1.43) by Mbiru et al. (2016). Fish condition factor is a crude measure of the level of energy reserve (i.e. nutritional status) in fish.
Reduction in condition factor is a sign of the poor condition of the fish. In this study, there was no significant difference in the condition factor among the treatments but lower condition factor in MST could indicate that the fish were not having a healthy nutritional status due to early maturity, which led to depressed growth.

The proportion of males in SRT was significantly higher than that of GMT. This was contrary to the expectation that the latter would produce a higher proportion of males. The results from this study contradict earlier studies by Beardmore et al. (2001) which indicated that genetically male tilapia has a sex rate of $99.58 \%$ males compared to $71.6 \%$ males in MST, and Kamaruzzaman et al. (2009) which had $94.3 \%$ of GMT and $71.3 \%$ of MST. This could be attributed to a possible inefficiency in the $Y Y$ male production procedure, which could have led to the unsuccessful $Y Y$ male production in a given batch, used in the production of the GMT fingerlings.

Water temperature affects the behaviour, growth, food intake, and food conversion of fish hence the determination of optimal temperature is essential in tilapia culture (El-Sayed et al., 1996). The growth of the different groups of fish was not significantly affected by the water quality parameters. However, overall water temperature recorded during the culture period was lower than the optimum range of $27-30^{\circ} \mathrm{C}$ recommended for Nile tilapia in ponds by Boyd \& Tucker (1998). The most preferred temperature range for optimal growth of tilapia is 27 to $30^{\circ} \mathrm{C}$, while the ideal $\mathrm{pH}$ ranges between 6 and 9 (Rakocy, 1989). From this study, the low water temperature could have led to the low growth observed in fish in all the experimental groups.

\section{Conclusion and Recommendation}

The sex-reversed Nile tilapia grew better than the other tilapia groups and had a low FCR, which indicates that the sex-reversed tilapia is more viable for pond aquaculture compared to the genetically male tilapia and the mixed-sex tilapia. The sex-reversed tilapia used less feed to grow and attained the market size faster than the other tilapia groups in this study. The results of this study indicate that sex reversal is a highly promising technology for application in the production of monosex Nile tilapia in Kenya and can result in substantial yields since it is highly adaptable to different agro-ecological zones. It is recommended that the performance of the genetically male tilapia from $Y Y$ technology be further evaluated in other on-farm environments and culture systems to determine its performance.

\section{Acknowledgement}

Kenya Marine and Fisheries Research Institute, Kenya provided the funds and logistics for this study. 


\section{References}

Adamneh, D. (2013). Comparative growth performance of monosex and mixed sex Nile tilapia (Oreochromis niloticus L.) in pond culture system at Sebeta, Ethiopia. International Journal of Aquaculture, 3(7), 30-34. https://doi.org/10.5376/ija.2013.03.0007

Allison, E. H. (2011). Aquaculture, fisheries, poverty and food Security. WorldFish Center Working Paper. Penang, Malaysia: WorldFish Center. Retrieved from http://pubs.iclarm.net/resource_centre/WF_2971.pdf

Amoussou, T. O., Abdou Karim, I. Y., Dayo, G. K., Kareem, N., Toko, I. I., Chikou, A., \& Toguyéni, A. (2019). An insight into advances in fisheries biology, genetics and genomics of African tilapia species of interest in aquaculture. Aquaculture Reports, 14, 100188.

https://doi.org/10.1016/j.aqrep.2019.100188

Ansah, Y. B., Frimpong, E. A., \& Hallerman, E. M. (2014). Genetically-improved tilapia strains in Africa: Potential benefits and negative impacts. Sustainability, 6(6), 3697-3721.

https://doi.org/https://doi.org/10.3390/su6063697

Azaza, M. S., Dhraïef, M. N., \& Kraïem, M. M. (2008). Effects of water temperature on growth and sex ratio of juvenile Nile tilapia, Oreochromis niloticus (Linnaeus) reared in geothermal waters in southern Tunisia. Journal of Thermal Biology, 33(2), 98-105. https://doi.org/10.1016/j.jtherbio.2007.05.007

Beardmore, J., Mair, G., \& Lewis, R. (2001). Monosex male production in finfish as exemplified by tilapia: applications, problems, and prospects. Aquaculture, 197(1-4), 283-301. https://doi.org/10.1016/S00448486(01)00590-7

Béné, C., Arthur, R., Norbury, H., Allison, E. H., Beveridge, M., Bush, S., Campling, L., Leschen, W., Little, D., Squires, D., Thilsted, S. H., Troell, M., \& Williams, M. (2016). Contribution of fisheries and aquaculture to food security and poverty reduction: Assessing the current evidence. World Development, 79, 177-196. https://doi.org/10.1016/j.worlddev.2015.11.007

Bhasin, S., Woodhouse, L., \& Storer, T. (2001). Proof of the effect of testosterone on skeletal muscle. Journal of Endocrinology, 170(1), 27-38. https://doi.org/10.1677/joe.0.1700027

Boyd, C. E., \& Tucker, C. S. (1998). Pond Aquaculture Water Quality Management. Boston, MA: Springer US. https://doi.org/10.1007/978-1-4615-5407-3

Celik, I., Guner, Y., \& Celik, P. (2011). Effect of orally administered $17 \alpha$-Methyltestosterone at different doses on the sex reversal of the Nile tilapia (Oreochromis niloticus, Linneaus 1758). Journal of Animal and Veterinary Advances, 10(7), 853-857.

https://doi.org/10.3923/javaa.2011.853.857

Chakraborty, S. B., Mazumdar, D., Chatterji, U., \& Banerjee, S. (2011). Growth of mixed sex and monosex Nile tilapia in different culture systems. Turkish Journal of Fisheries and Aquatic Sciences, 11(1), 133-140. https://doi.org/10.4194/trjfas.2011.0117

Chakraborty, S. B., \& Banerjee, S. (2012). Comparative growth performance of mixed-sex and monosex Nile tilapia at various stocking densities during cage culture. Recent Research in Science and Technology 2012, 4(11), 46-50.

Charo-Karisa, H., Komen, H., Rezk, M. A., Ponzoni, R. W., van Arendonk, J. A. M., \& Bovenhuis, H. (2006). Heritability estimates and response to selection for growth of Nile tilapia (Oreochromis niloticus) in low-input earthen ponds. Aquaculture, 261(2), 479-486.

https://doi.org/10.1016/j.aquaculture.2006.07.007

Chen, J., Fan, Z., Tan, D., Jiang, D., \& Wang, D. (2018). A review of genetic advances related to sex control and manipulation in tilapia. Journal of the World Aquaculture Society, 49(2), 277-291. https://doi.org/10.1111/jwas.12479

Chu, L., Phillips, M. J., Chan, C. Y., Tran, N., Kefi, A. S., \& Genschick, S. (2018). Fish supply and demand for food security in Sub-Saharan Africa: An analysis of the Zambian fish sector. Marine Policy, 99, 343-350. https://doi.org/10.1016/j.marpol.2018.11.009

El-Greisy, Z. A., \& El-Gamal, A. E. (2012). Monosex production of tilapia, Oreochromis niloticus using different doses of $17 \alpha$-methyltestosterone with respect to the degree of sex stability after one year of treatment. Egyptian Journal of Aquatic Research, 38(1), 59-66. https://doi.org/10.1016/j.ejar.2012.08.005

El-Sayed, A.-F. M., El-Ghobashy, A., \& Al-Amoudi, M. (1996). Effects of pond depth and water temperature on the growth, mortality and body composition of Nile tilapia, Oreochromis niloticus (L.). Aquaculture Research, 27(9), 681-687. https://doi.org/10.1046/j.1365-2109.1996.00776.x

FAO. (2018). The state of world fisheries and aquaculture 2018 - Meeting the sustainable development goals. Rome, Italy: FAO, Fisheries Department. Retrieved from www.fao.org/documents/card/en/c/19540EN

Fitzsimmons, K. M. (2000). Tilapia: the most important aquaculture species of the 21st century. In Proceedings from the Fifth International Symposium on Tilapia Aquaculture (pp. 3-8). Rio de Janeiro, Brazil.

Froese, R. (2006). Cube law, condition factor and weightlength relationships: history, meta-analysis and recommendations. Journal of Applied Ichthyology, 22(4), 241-253. https://doi.org/10.1111/j.1439-0426.2006.00805.x

Githukia, C. M., Ogello, E. O., Kembenya, E. M., Achieng, A. O., Obiero, K. O., \& Munguti, J. M. (2015). Comparative growth performance of male monosex and mixed sex Nile tilapia (Oreochromis niloticus L.) reared in earthen ponds. Croatian Journal of Fisheries, 73(1), 20-25. https://doi.org/10.14798/73.1.788

Islam, Z. M., Sarder, R. I., \& Akhand, R. I. (2015). Growth performance of genetically male tilapia derived from $Y Y$ male, sex reversed male tilapia and mixed sex tilapia of Oreochromis niloticus in earthen pond aquaculture system in Bangladesh. International Journal of Fisheries and Aquatic Studies, 2(3), 186-191. Retrieved from http://www.fisheriesjournal.com/vol2issue3/Pdf/47.1.p df

Kamaruzzaman, N., Nguyen, N. H., Hamzah, A., \& Ponzoni, R. W. (2009). Growth performance of mixed sex, hormonally sex reversed and progeny of YY male tilapia of the GIFT strain, Oreochromis niloticus. Aquaculture Research, 40(6), 720-728. https://doi.org/10.1111/j.1365-2109.2008.02152.x

Khalil, W. K. B., Hasheesh, W. S., Marie, M. A. S., Abbas, H. H., \& Zahran, E. A. (2011). Assessment of the impact of the $17 \alpha$-methyltestosterone hormone on growth, hormone concentration, molecular and histopathological changes in muscles and testis of Nile tilapia, Oreochromis niloticus. Life Science Journal, 8(3), 329-343. 
KMFRI. (2017). Kenya's Aquaculture Brief: status, trends, challenges, and future Outlook. Mombasa, Kenya, 12pp.

Kumar, G., \& Engle, C. R. (2016). Technological advances that led to growth of shrimp, salmon, and tilapia farming. Reviews in Fisheries Science and Aquaculture, 24(2), 136-152. https://doi.org/10.1080/23308249.2015.1112357

Liti, D., Cherop, L., Munguti, J., \& Chhorn, L. (2005). Growth and economic performance of Nile tilapia (Oreochromis niloticus L.) fed on two formulated diets and two locally available feeds in fertilized ponds. Aquaculture Research, 36(8), 746-752. https://doi.org/10.1111/j.1365-2109.2005.01265.x

Lugert, V., Thaller, G., Tetens, J., Schulz, C., \& Krieter, J. (2016). A review on fish growth calculation: multiple functions in fish production and their specific application. Reviews in Aquaculture, 8(1), 30-42. https://doi.org/10.1111/raq.12071

Mair, G.C., \& Little, D. C. (1991). Population control in farmed tilapias. Naga, the ICLARM Quarterly, 14(3), 8-13. Retrieved from http://www.worldfishcenter.org/Naga/na_2834.pdf

Mair, Graham C., Abucay, J. S., Beardmore, J. A., \& Skibinski, D. O. F. (1995). Growth performance trials of genetically male tilapia (GMT) derived from YY-males in Oreochromis niloticus L.: On station comparisons with mixed sex and sex reversed male populations. Aquaculture, 137(1-4), 313-323. https://doi.org/10.1016/0044-8486(95)01110-2

Mair, G C, Abucay, J. S., Skibinski, D. O. F., Abella, T. A., \& Beardmore, J. A. (1997). Genetic manipulation of sex ratio for the large-scale production of all-male tilapia, Oreochromis niloticus. Canadian Journal of Fisheries and Aquatic Sciences, 54(1991), 396-404

Mamun, A., Sarder, R. I., \& Rahman, M. M. (2016). Growth performance of genetically male (GMT) and hormone induced sex reversed male tilapia (Oreochromis niloticus L.) in earthen pond aquaculture system. Bangladesh Journal of Zoology, 38(2), 163-169.

Mateen, A., \& Ahmed, I. (2007). Effect of androgen on sex reversal and growth of Nile tilapia (Oreochromis niloticus). Pakistan Journal of Agricultural Sciences, 44(2), 272-276.

Mbiru, M., Limbu, S. M., Chenyambuga, S. W., Lamtane, H. A., Tamatamah, R., Madalla, N. A., \& Mwandya, A. W. (2016). Comparative performance of mixed-sex and hormonal-sex-reversed Nile tilapia Oreochromis niloticus and hybrids (Oreochromis niloticus $\times$ Oreochromis urolepis hornorum) cultured in concrete tanks. Aquaculture International, 24(2), 557-566. https://doi.org/10.1007/s10499-015-9946-z

Mbugua, M. H. (2008). Aquaculture in Kenya; status, challenges and opportunities. Nairobi, Kenya, 10pp. Retrieved from https://www.oceandocs.org/handle/1834/7367

Ngugi, C. C., Bowman, J. R., \& Omolo, B. (2007). A new guide to fish farming in Kenya. Oregon, USA: Aquaculture Collaborative Research Support Program (ACRSP) Aquaculture CRSP Management Office, Oregon University, Oregon USA. 100pp. Retrieved from http://pdacrsp.oregonstate.edu/pubs/featured_titles/K enya_Manual.pdf

Nyonje, B. M., Opiyo, M. A., Orina, P. S., Abwao, J., Wainaina, M., \& Charo-Karisa, H. (2018). Current status of freshwater fish hatcheries, broodstock management and fingerling production in the Kenya aquaculture sector. Livestock Research for Rural Development, 30(1).

Opiyo, M. A., Marijani, E., Muendo, P., Odede, R., Leschen, W., \& Charo-Karisa, H. (2018). A review of aquaculture production and health management practices of farmed fish in Kenya. International Journal of Veterinary Science and Medicine, 6(2), 141-148. https://doi.org/10.1016/j.ijvsm.2018.07.001

Phelps, R. P., \& Popma, T. J. (2000). Sex reversal of tilapia. In B. A. Costa- Pierce \& J. E. Rakocy (Eds.), Tilapia Aquaculture in the Americas (pp. 34-59). Baton Rouge, Louisiana, USA: The World Aquaculture Society.

Singh, E., Saini, V. P., Sharma, O. P., Ojha, M. L., \& Jain, H. K. (2017). Comparative growth performance of monosex and mixed sex red tilapia (Oreochromis niloticus L.). Journal of Entomology and Zoology Studies, 5(6), 10731075.

Sogard, S. M. (1997). Size-selective mortality in the juvenile stage of teleost fishes: A review. Bulletin of Marine Science, 60(3), 1129-1157.

Rakocy, J. E. (1989). Tank Culture of Tilapia (Issue 282). Southern Regional Aquaculture Center, Texas USA, 4pp. https://cals.arizona.edu/azaqua/extension/Classroom/ pdffiles/282fs.pdf

Toguyeni, A., Fauconneau, B., Boujard, T., Fostier, A., Kuhn, E. R., Mol, K. A., \& Baroiller, J. F. (1997). Feeding behaviour and food utilisation in tilapia, Oreochromis niloticus: Effect of sex ratio and relationship with the endocrine status. Physiology and Behavior, 62(2), 273-279. https://doi.org/10.1016/S0031-9384(97)00114-5 